$\underline{\text { www.elkjournals.com }}$

\title{
PERFORMANCE EVALUATION OF ACTIVE MUTUAL FUNDS IN INDIA
}

\begin{tabular}{|l|l|}
\hline Sumana B.K & Prof B.Shivaraj \\
Research Scholar, & Professor, \\
B.N. Bahadur Institute of Management Sciences, University & B.N. Bahadur Institute of Management Sciences, University \\
of Mysore, Mysore & of Mysore, \\
Email: Suman_dravid@yahoo.co.in & Mysore, India
\end{tabular}

\section{ABSTRACT}

Active management is the predominant model for investment strategy today. The objective with active management is to produce better returns than those of passively managed funds. There is a perennial debate between active management and passive management. The study focuses on performance evaluation of actively managed mutual funds. With the importance of risk and return for any investment, this paper analyses risk adjusted returns of mutual funds and also absolute returns. The study focuses on finding the performance of selected actively managed mutual funds using different performance measures like Sharpe's, Jensen's Alpha and Information ratio. Using these measures, we have attempted to find out if the fund managers have outperformed the benchmark for a given risk class. The sample selected for the study is ten Large Capitalization Mutual funds in India. The period of study is three years (2010-13). The analysis was on the basis of quarterly, half yearly, yearly returns for each mutual fund. The results revealed that the returns varied with the frequency of measurement. This shows the time is an important dimension in the performance of the fund. The study also revealed that the type of measure selected has a bearing on the performance of asset managers. While the fund(s) may perform better according to a given method than other funds of the same risk class and vice versa. This reveals that the selection of performance measure is very important in assessing the performance of the mutual fund.

Keywords: Active Fund, Index Fund, Beta, Tracking Error, Alpha, Information Ratio

\section{Introduction}

Active management refers to a portfolio management strategy where the manager makes specific investments with the goal of outperforming an investment benchmark index. The aim of the active management is to beat the market. Active portfolio managers attempt to construct a risky portfolio that maximizes the reward-to-variability (Sharpe) ratio. Active fund managers pick undervalued stocks that will outperform the index. Active managers depend on superior stock selection and market timing to beat the benchmark. A truly passive portfolio strategy entails holding the market index portfolio and a money market fund. In passive management, investors expect a return that closely replicates the investment weighting(broader asset allocation) and returns of a benchmark index and will often invest in an index fund or Exchange Traded Fund(ETF`s).
The investment management fee for an active management is higher than passive management. There are tradeoffs between the costs and potential benefits of the two approaches. Each has its merits and inherent drawbacks. Sharpe (1999) mentions that the before costs the average actively managed dollar will equal the return on the average passively managed dollar and after costs, the return on the average actively managed dollar will be less than the return on the average passively managed dollar The mutual fund shareholders with higher risk tolerance, look for actively managed funds that can outperform the Index. The lure into active management due to the potential profit from active strategies is enormous. At the same time, competition among the multitude of active managers creates the force driving market prices to near-efficiency levels. Although enormous profits may be increasingly difficult to earn, decent profits can 


\section{ELK Asia Pacific Journals}

$\underline{\text { www.elkjournals.com }}$

be made. The investors have to pay fees for actively managing the fund to produce excess return of the fund relative to the return of the benchmark index known as alpha. Even if the pre fee return beats the market, the fund management fees bring down the net asset value (NAV) in relation to its benchmark. According to the research conducted by NERD Wallet (an Investment management Company) in 2013, only $24 \%$ of the active managers beat the market over the past ten years. A study by Barclays Global Investors published in 2008, Between 31 December 1992 and 31 December 2007, only $41.6 \%$ of the actively managed US large company funds that beat the S\&P 500 Index in a particular year were able to outperform the next year. Mercer, an investment consulting firm conducted a study on Indian Equity mutual fund in May 2011, classified the mutual funds and measured the performance with appropriate benchmarks. It then analyzed the fund performance vis-a-vis the newly defined benchmarks and found that $70 \%$ of large-cap funds outperformed the BSE-100. However, only $55 \%$ managed to do so over a five-year period. Among the diversified equity funds, $63 \%$ yielded returns in excess of their benchmark, the BSE500 Index. This ratio dropped to $52 \%$ for the five-year period. Mid-cap funds have fared poorly. While $61 \%$ beat the benchmark index (CNX Midcap) over the three-year time frame, only $32 \%$ managed to outperform over the fiveyear term.

\section{Literature Review}

Lubo`s P'astor et al 2014: The authors have empirically analyzed the nature of returns to scale in active fund management. The study found strong evidence of decreasing returns at the industry level. As the size of the mutual fund industry increases, the funds ability to outperform passive benchmark decreases. At the fund level, all methods considered indicate decreasing returns.

Antti Petajisto 2013: In this paper, the author has sorted all the equity mutual fund into various active management. The author uses active share and tracking error to sort all the domestic equity mutual fund into five types of categories on the type of active management they practice. $\mathrm{He}$ concluded that average actively managed mutual fund underperformed its benchmark index. $\mathrm{He}$ found that the most active stock pickers add value for their investors beating their benchmark index by $1.26 \%$ a year after all fees and expenses.

Barclay`s Global Investors 2008:The study conducted by them from 1992-2007 on US actively managed mutual funds and found that only $41.6 \%$ of the actively managed large company funds that beat the S\&P 500 Index in a particular year were able to outperform the next year. After three years, only $9.7 \%$ of the original set of outperformers was still beating the index.

David Blake et all (2014): According to this study, which examined the monthly returns of 516 UK domestic equity open ended mutual funds between 1998-2008 revealed an annual post fee alpha return of minus 1.44 percent. Most 


\section{ELK Asia Pacific Journals}

$\underline{\text { www.elkjournals.com }}$

of the active fund managers fail to outperform the market once the fess is extracted from the returns. The research also points out that only one percent of the fund managers can deliver superior performance in excess of operating and trading costs.

According to Vanguard`s whitepaper (2013), which analyzed US domestic stock fund performance for the 15 year period 1997 through 2011. Using data supplied by Morningstar, the study reported that $46 \%$ of actively managed domestic stock funds outperformed their benchmark index in the five years ending December 31, 2011. But the percentage of outperformers declined to $32 \%$ when increased the period under study to the prior 10 years and $27 \%$ for the full 15 years.

Mallikarjuna Rao and Ranjeeta Rani(2013), They have studied 10 balanced mutual funds using various risk adjusted measures and found that The overall analysis JM Balanced-G (-0.0282) and Kotak Balanced fund (-0.6974) schemes managers have poor stock selection skills.

Lubos Pastor et al (2012), argues that active management poor track record has resulted in growth of Index funds. This has reduced the share of investment in active management. With the increase in industry size the fund managers find difficulty in outperforming the benchmark. Active management industry faces decreasing returns to scale i.e. any fund manager's ability to outperform a passive benchmark declines as the industry's size increases. The authors use a model with competing investors and fund managers; they found that large observed size of the active management industry can be rationalized if investors believe that active managers face decreasing returns to scale.

Sahil Jain (2012): The author has analyzed the performance of equity mutual funds using the risk-return relationship and Capital Asset Pricing Model (CAPM). A total of 45 schemes offered by 2 private sector companies and 2 public sector companies, have been studied over the period April 1997 to April 2012 (15 years). It revealed that HDFC and ICICI have been the best performers and LIC the worst performer.

Nicolas P. B. Bollen et al (2004): In this article, the authors examine the persistency of mutual fund for short period of time. They have ranked funds every quarter by their risk adjusted return measured over three month period using stock selection, market timing and mixed strategy models. Then the risk adjusted return of deciles of funds is measured for these three months. They found that the top decile of funds generated a statistically significant abnormal return in the post ranking quarter of 25-39 basis points across the performance models. The post ranking abnormal returns disappear when funds are evaluated over long period of time. This result shows that superior performance is a temporary phenomenon that is observable only when funds are evaluated several times a year.

Chen et al (2000): The paper investigates that stocks that are most widely held by mutual funds do not outperform stocks that are least widely held. The stocks that are actively traded by the 


\section{ELK Asia Pacific Journals}

$\underline{\text { www.elkjournals.com }}$

mutual funds outperform stocks that are held from prior periods. The study also reveals that growth-oriented funds exhibit better stock selection skills than income-oriented funds, specifically, in picking large growth stocks. The authors also found that funds that trade more frequently have marginally better stock selection skills than funds trading less often. Finally, they found that much of the persistence in fund performance was due to the momentum effect in stock returns.

The literature review reveals that most of the actively managed mutual funds find difficulty in outperforming their respective index. The outperformance of the mutual funds declines when the funds are evaluated for longer period and the frequency of performance measurement. Most of the study focuses on US, UK and other developed nations. Even though many researches have been conducted on performance evaluation of mutual funds in India, but there is no distinction made between active and passive management style of fund management. Mutual funds in India are gaining popularity which is evident from the increasing asset under management. Indian investors have a wide spectrum of nearly 1000(Source: NSEIndia) mutual fund schemes to invest. So it becomes imperative that the investors are aware of the risk and return of investing in mutual funds. Therefore the study attempts to analyze the performance of actively managed mutual funds in India. This study helps both the investors to analyze their existing mutual funds holding and the prospective investors to make informed investment decisions. The study also helps the fund managers to compare their fund performances with their peers.

\section{Objectives}

1. To evaluate and analyze quarterly, half yearly, yearly, performance analysis of actively managed mutual fund on the basis of percentage returns in respective periods.

2. To investigate if actively managed mutual funds outperform their respective benchmarks (BSE 200, BSE 100 \& Nifty).

3. To evaluate the performance of select mutual funds in terms of risk and return using major statistical measures namely Standard deviation, beta, coefficient of correlation and Coefficient of determination.

4. To rank the selected mutual fund according to Sharpe`s, Jensen`s Alpha and Information ratio performance measures on the basis of the results obtained for statistical indicators namely Standard deviation, beta, coefficient of correlation and Coefficient of determination .

\section{Research Methodology}

The returns of the fund can be evaluated on absolute returns or returns adjusted for risk. The absolute returns of the funds and their benchmark are calculated from daily returns in the frequency of quarterly, half yearly and annually using geometric linking. 


\section{ELK Asia Pacific Journals}

$\underline{\text { www.elkjournals.com }}$

The formula used is given as under:

$\left(1+\mathrm{S}_{1}\right) *\left(1+\mathrm{S}_{2}\right) * \ldots \ldots \ldots . .\left(1+\mathrm{S}_{\mathrm{n}}\right)-1$

Where, $S_{1}=$ First daily return for the month,

$\mathrm{S}_{2=}$ Second daily return for the month

$\mathrm{S}_{\mathrm{n}}=$ Last daily return for the month

Investors have a visible tendency to focus more on investment returns than returns that are adjusted for risk. The performance of the portfolio has to be measured both in terms of risk and return to be compared meaningfully. The risk adjusted performance measures that would be used are listed below:

Sharpe Ratio: The CAPM model of risk adjusted performance evaluation and mean variance criteria came on stage simultaneously. It considers total risk (standard deviation).Higher the ratio better is the funds performance and vice versa. The formula to find Sharpe ratio is:

Sharpe Ratio (S.R) $=\left(\bar{r}_{p}-\bar{r}_{f}\right) / \sigma_{p}$

Jensen Alpha: On the basis of Sharpe`s CAPM expected return, Jensen measures the average return over and above the expected return. Jensen`s measure is the portfolio`s alpha value. While higher the alpha better is the performance of the fund. It shows if the portfolio manager has outperformed the CAPM expected return or the returns of the benchmark index.

Jensen`s Alpha (J.A)

$\alpha_{P}=\bar{r}_{P}-\left[\bar{r}_{f}+\beta_{P}\left(\bar{r}_{M}-\bar{r}_{f}\right)\right]$
Information Ratio: A generalized version of Sharpe ratio is Information ratio. The information ratio tells an investor how much excess return is generated from the amount of excess risk taken relative to the benchmark index. The information ratio divides the alpha of the portfolio by the non systematic risk of the portfolio called tracking error.

Information Ratio (I.R) $=\infty_{p} / \sigma\left(e_{p}\right)$

Apart from the above measures, To find the volatility of returns Standard deviation is calculated. We also use multiple ' $R$ ' (coefficient of correlation) to study the extent of correlation between the performance of the fund and the market. $\mathrm{R}^{2}$ (coefficient of determination) to find the explained and unexplained parts of the volatility. Also beta is calculated to find the systematic risk of the mutual funds. Excel has been used extensively for computations.

Where,

$\bar{r}_{P=}$ Portfolio average return

$\bar{r}_{f_{,}}=$Average risk free return

$\sigma_{P}=$ portfolio standard deviation

$\beta_{\mathrm{p}}=$ Portfolio beta

$\alpha_{p}=$ Portfolio alpha(portfolio excess return over expected return)

$\sigma\left(e_{p}\right)=$ tracking error or portfolio unsystematic error 


\section{ELK Asia Pacific Journals}

$\underline{\text { www.elkjournals.com }}$

Despite having so many measures, the performance of the funds depends on many factors like market conditions, frequency of performance measured. Each measure does not necessarily provide consistent assessments of performance, since the risk measure used to adjust returns differ substantially. It is important to note that the comparison has to be among the same asset classes and appropriate benchmark has to be considered.

Of the many mutual funds available in India, we have selected randomly ten star rated mutual funds from the growth funds. Out of which we have considered ten large capitalization funds. The table showing the sample of mutual funds and their benchmark is given in the annexure $\mathrm{A}$. The data has been sourced from bluechipindia.com, BSE and NSE websites for the financial years 2008-2009 to 2012-2013. We have analyzed the performance of the funds in the frequencies of quarterly, half yearly, yearly. The performance measurement ratios were computed on yearly basis. Thus we have tried to analyze the performance of select mutual funds using both pure returns (without adjusting for risk) and risk adjusted return. This helps us to compare between traditional performance measurement and risk adjusted performance measures. Also we can find if the returns have outperformed their respective benchmark.

\section{Limitations}

The sample considered for the study is ten large capitalization mutual funds for a period of three years, to gain greater insights more number of funds can be studied; also period of study can also be increased. Literature reviewed is also limited. The other limitation is that the returns are not adjusted for the asset management fees and other expenses.

\section{Data Analysis and Findings}

\section{Quarterly Performance}

Quarterly Performance for Financial Year 2010-11:

(a)Axis Equity, Birla Top 100, Reliance focused Large Cap \& Benchmark Nifty:

Nifty has not performed well in the first quarter with $0.42 \%$ returns, All the three mutual funds Axis, Birla Top 100 and reliance have outperformed the index with Axis fund delivering $2.47 \%$ returns. In the second quarter Nifty has given $13.50 \%$ returns, Axis, Birla Top 100 and reliance have underperformed the index with Reliance being the worst performer of $4.20 \%$ returns. In the third quarter Nifty has performance of $1.73 \%$, whereas, Axis, reliance have negative figures except for Birla Top 100 fund being an outperformer. In the last quarter all the three funds Axis, Birla Top 100, Reliance and the Nifty has given negative returns.

(b)Hdfc Top 200, Can Robeco, Franklin India, ICICI Top 200 JP Morgan \& Benchmark BSE 200

BSE 200 has delivered a return of $2.21 \%$ in first quarter; almost all the above funds except Franklin India have outperformed their benchmark and Hdfc 200 being the top 


\section{ELK Asia Pacific Journals}

$\underline{\text { www.elkjournals.com }}$

performer. In comparison with the benchmark, all the funds have outperformed BSE 200 except for Canara Robeco. Again HDFC is the top performer in this quarter also with $15.50 \%$ returns. In the third quarter, all the funds and the index has performed poorly. In the last quarter, all the funds and the Index have negative returns.

(c) SBI Bluechip, UTI Equity and Benchmark BSE 100

The Index does not have an impressive performance in the first quarter with only $0.73 \%$. Both the funds have outperformed the index. In the second quarter, UTI has outperformed the benchmark. Again in the third quarter UTI has outperformance whereas SBI has underperformed. In the last quarter BSE 100 has delivered negative returns so are the two funds.

\section{Quarterly Performance for Financial Year}

\section{1-12:}

(a)Axis Equity, Birla Top 100, Reliance focused Large Cap \& Benchmark Nifty

Including the benchmark, the above funds have performed badly with negative returns in the first, second and third quarters. In the last quarter, Nifty has a performance of $14.52 \%$ and Birla sunlife outperforming the index with $16.18 \%$ returns.

(b)Hdfc Top 200, Can Robeco, Franklin India, ICICI Top 200 JP Morgan \& Benchmark BSE 200

Except for Canara Robeco (1.49\%) all the above funds and Index have delivered negative returns in the first quarter. All the funds and benchmark have delivered negative returns in second and third quarter. Only in the last quarter that the Index has given $16.59 \%$ and with ICICI Top 200 being a top performer.

(c) SBI Bluechip, UTI Equity and Benchmark BSE 100

In the first, second and third quarters including the index and the funds have delivered negative returns. We can find that only in the last quarter that both Index and the funds have given good returns, but with no fund outperforming the index.

\section{Quarterly Performance for Financial Year 2012-13:}

(a)Axis Equity, Birla Top 100, Reliance focused Large Cap \& Benchmark Nifty

In the first quarter all the above funds including the benchmark have given negative returns, With Reliance, Birla and Axis respectively beating the index in the second quarter. In the third quarter, all the funds have outperformed the index. In the last quarter all the funds including the index have negative returns.

(b)Hdfc Top 200, Can Robeco, Franklin India, ICICI Top 200 JP Morgan \& Benchmark BSE 200

In first quarter, except for Canara Robeco, all the funds have negative returns including the benchmark. ICICI and Franklin India respectively outperformed the benchmark in the second quarter. In the third quarter BSE 200 has give $5.06 \%$ return. Whereas only Hdfc (5.47\%) and Franklin (5.76\%) have outperformed, the 


\section{ELK Asia Pacific Journals}

$\underline{\text { www.elkjournals.com }}$

other two funds have underperformed the Index.

In the last quarter all the funds including the benchmark have negative performance.

(c) SBI Bluechip, UTI Equity and Benchmark BSE 100

In the first and the last quarter, the benchmark has given negative results. Even though the funds Table 1: Quarterly return in \% of sample and index funds

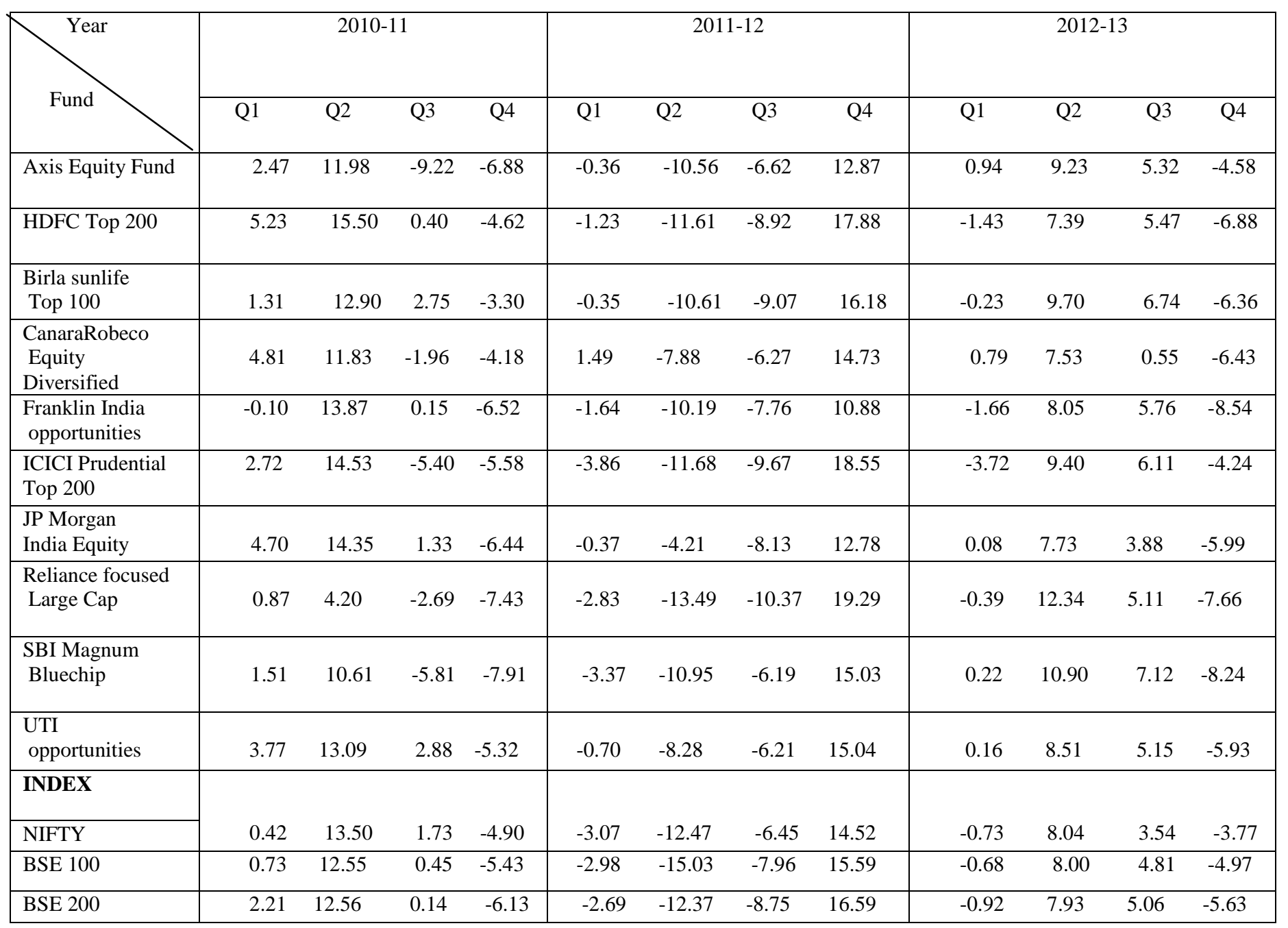

Reliance has delivered poor returns when

Half Yearly Performance (HY)

\section{HY Performance for Financial Year 2010-11:}

(a)Axis Equity, Birla Top 100, Reliance focused Large Cap \& Benchmark Nifty have outperformed in the first quarter but the outperformance is very less. In the last quarter both the funds have negative returns. In the third \& fourth quarter, both SBI \& UTI have outperformed the index

The quarterly returns of the sample funds and Benchmark are listed in Table 1 below compared to its peer and the benchmark in the first half year. Axis equity and Birlasunlife has beaten the benchmark. In the second half year, the Nifty has negative returns $(-3.25 \%)$. Axis equity has the highest negative returns. 


\section{ELK Asia Pacific Journals}

$\underline{\text { www.elkjournals.com }}$

(b)Hdfc Top 200, Can Robeco, Franklin India, ICICI Top 200 JP Morgan \& Benchmark BSE 200

The Index has given $15.05 \%$ returns, Except Franklin India fund all the other funds have outperformed in first half year. All the funds including the benchmark have negative performance in the second half year.

(c) SBI Bluechip, UTI Equity and Benchmark BSE 100

UTI equity has outperformed the benchmark in the first half year. In the second half year SBI magum and UTI have performed badly in comparison with the index.

\section{HY Performance for Financial Year 2011-12:}

(a)Axis Equity, Birla Top 100, Reliance focused Large Cap \& Benchmark Nifty

Nifty has given a negative return of $15.15 \%$, both Birla and Reliance have also given negative returns except for Axis which has given $10.89 \%$ in first half year. In the second half year no fund was able to beat the index.

(b)Hdfc Top 200, Can Robeco, Franklin India, ICICI Top 200 JP Morgan \& Benchmark BSE 200

Including the benchmark, the funds have delivered negative returns in the first half year. Except for JP Morgan all the other have outperformed the Index in the second half year. (c) SBI Bluechip, UTI Equity and Benchmark BSE 100

BSE 100 has given negative returns so are the other two funds in the first half year. UTI has outperformed whereas SBI has underperformed the index in the second half year.

\section{HY Performance for Financial Year 2012-13:}

(a)Axis Equity, Birla Top 100, Reliance focused Large Cap \& Benchmark Nifty

All the above three funds have outperformed Nifty in first half year. Including the benchmark all the funds have given negative returns in the second half year.

(b)Hdfc Top 200, Can Robeco, Franklin India, ICICI Top 200 JP Morgan \& Benchmark BSE 200

Canara Robeco and JP Morgan were able to beat the index in the first half year. Whereas HDFC and Franklin and ICICI have been underperformers. In the second half year, Except for Franklin \& ICICI others have given negative returns.

(c) SBI Bluechip, UTI Equity and Benchmark BSE 100

Both of the above funds have outperformed the Index in the first half year. Including the benchmark the funds have delivered negative returns.

The half Yearly returns of sample and benchmark are given below 


\section{[】 ELK Asia Pacific Journals}

www.elkjournals.com

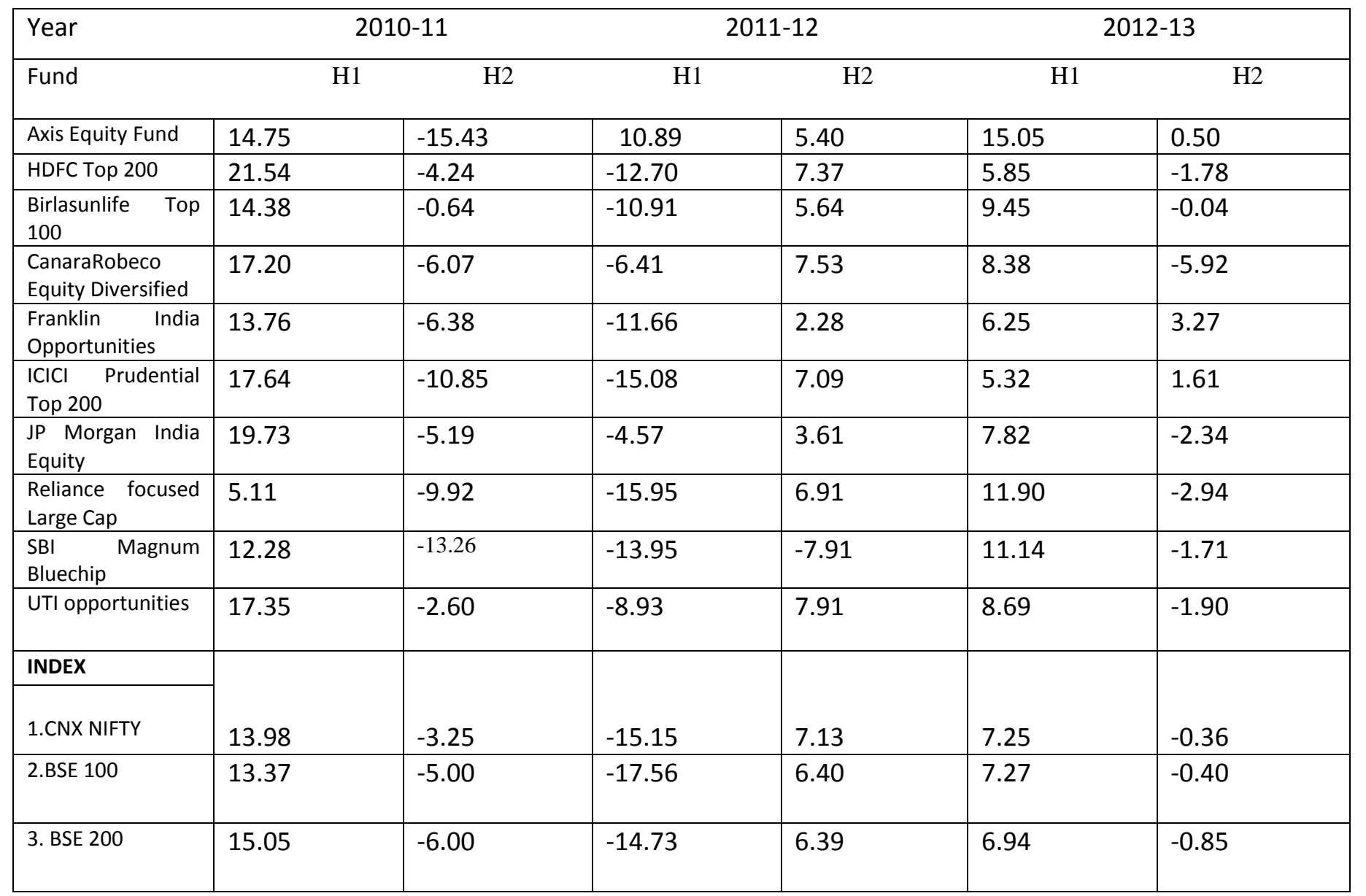

HDFC Top 200 has a stellar performance of

\section{Yearly Performance}

The relevant data pertaining to the yearly performance is summarized in the Table 3. After analyzing the quarterly and half yearly data, we turn our focus towards yearly performance.

\section{Yearly Performance for Financial Year 2010-}

11:

(a)Axis Equity, Birla Top 100, Reliance focused Large Cap \& Benchmark Nifty

Birla Top 100 is the only fund that has beaten the market; Axis Equity and Reliance have performed very badly with negative returns.

(b)Hdfc Top 200, Can Robeco, Franklin India, ICICI Top 200 JP Morgan \& Benchmark BSE 200
$16.39 \%$ as against BSE200 8.15\% Canara

Robeco and JP Morgan funds have also outperformed the index.

(c) SBI Bluechip, UTI Equity and Benchmark BSE 100

UTI Equity has given a good outperformance against its benchmark of $14.30 \%$ whereas SBI has given negative returns.

Yearly Performance for Financial Year 201112:

(a)Axis Equity, Birla Top 100, Reliance focused Large Cap \& Benchmark Nifty

All the funds including the benchmark have delivered negative returns. 


\section{ELK Asia Pacific Journals}

$\underline{\text { www.elkjournals.com }}$

(b)Hdfc Top 200, Canara Robeco, Franklin India, ICICI Top 200 JP Morgan \& Benchmark BSE 200

All the funds except Canara Robeco have given negative returns including the index.

(c) SBI Bluechip, UTI Equity and Benchmark BSE 100

Both the funds and benchmark have delivered negative returns.

\section{Yearly Performance for Financial Year 2012-} 13:

(a)Axis Equity, Birla Top 100, Reliance focused Large Cap \& Benchmark Nifty

All the funds have outperformed the benchmark, with Axis Equity being the top performer.

(b)Hdfc Top 200, Canara Robeco, Franklin India, ICICI Top 200 JP Morgan \& Benchmark BSE 200

Only ICICI Top 200 has outperformed the benchmark and others have underperformed.

(c) SBI Bluechip, UTI Equity and Benchmark BSE 100

Both the funds have beaten the index.

Table 3: Yearly Returns in \% of sample and $\underline{\text { index funds }}$

\begin{tabular}{|l|c|c|c|}
\hline Year/ Fund & $2010-11$ & $2011-12$ & $2012-13$ \\
\hline Axis Equity Fund & -2.95 & -6.08 & 15.62 \\
\hline HDFC Top 200 & 16.39 & -6.27 & 3.96 \\
\hline Birlasunlife Top & 13.65 & -5.89 & 9.41 \\
\hline
\end{tabular}

\begin{tabular}{|l|c|c|c|}
\hline 100 & 10.09 & 0.64 & 1.97 \\
\hline $\begin{array}{l}\text { Canara Robeco } \\
\text { Equity } \\
\text { Diversified }\end{array}$ & 6.50 & -9.64 & 2.78 \\
\hline $\begin{array}{l}\text { Franklin India } \\
\text { Opportunities }\end{array}$ & 4.88 & -9.07 & 7.02 \\
\hline $\begin{array}{l}\text { ICICI Prudential } \\
\text { Top 200 }\end{array}$ & 13.52 & -1.12 & 5.29 \\
\hline $\begin{array}{l}\text { JP Morgan India } \\
\text { Equity }\end{array}$ & -5.31 & -10.13 & 8.61 \\
\hline $\begin{array}{l}\text { Reliance focused } \\
\text { Large Cap }\end{array}$ & -2.61 & -7.14 & 9.24 \\
\hline $\begin{array}{l}\text { SBI Magnum } \\
\text { Bluechip }\end{array}$ & 14.30 & -1.78 & 7.5 \\
\hline $\begin{array}{l}\text { UTI } \\
\text { Opportunities }\end{array}$ & 10.27 & -9.11 & 6.86 \\
\hline INDEX: NIFTY & 7.70 & -12.28 & 6.84 \\
\hline $\begin{array}{l}\text { INDEX: BSE 100 } \\
\text { INDEX: BSE 200 }\end{array}$ & 8.15 & -9.28 & 6.03 \\
\hline
\end{tabular}

The important inference that can be drawn from the analysis of quarterly, half yearly and yearly returns is that there is no consistency in the performance of the mutual funds irrespective of the frequency of measurement. There is also no persistency in outperformance of the funds with respect to their benchmark. The returns varied across the different measurement periods The analysis also shows that superior performance is short-lived that can be observed only if the mutual funds are evaluated many times a year.

Apart from analyzing the returns on the basis of various frequencies, we have also computed some of the important statistical measures to comprehend the risk factor in the returns. Some of the measures used are Standard deviation (S.D.), beta co-efficient ( $\beta$ ), multiple $R$ 


\section{ELK Asia Pacific Journals}

$\underline{\text { www.elkjournals.com }}$

and $\mathrm{R}^{2}$. Beta co-efficient $(\beta)$, multiple $\mathrm{R}$ and $\mathrm{R}^{2}$ have been calculated using regression analysis between the funds return and their respective benchmark for the years 2010-11 to 2012-13. Standard deviation calculated is annualized. The values are tabulated in Table 4. The detailed analysis of the above statistical measures is below

\section{$\underline{\text { Standard deviation }}$}

(a)FY 2010-11: The lowest standard deviation is Reliance Large Cap and the highest standard deviation is Axis Equity.

(b)FY 2011-12: The standard deviations are high among all the funds with JP Morgan the least. Even in the annual returns all the funds have negative returns including the benchmark.

(c)FY 2012-13: The standard deviation is very low for Reliance Large Cap, whereas SBI Magnum is highest.

The standard deviation of all the funds is more when compared with their respective benchmarks in all the years. Reliance large Cap standard deviation is very less when compared to its benchmark Nifty in the year 2010-11 \& 2012-13. In the year 2012-13 there was lot of volatility, which is visible in both returns and the standard deviations of the benchmarks and the funds

\section{$\underline{\text { Beta Coefficient }}$}

(a)FY 2010-11: All the funds have beta less than 0.5, Franklin India has least beta figure, SBI Magnum has negative beta.
(b)FY 2011-12: Reliance Large cap has zero beta which indicates that there is no correlation with nifty. Canara Robeco has the least beta value. ICICI has negative beta values.

(c)FY 2012-13: Beta values are very low in this year in the range of $0.01-0.16$.

The beta coefficients of the samples are less than 1 , indicating that the funds returns are less sensitive to that of the benchmark. Reliance large cap is the only fund which has got zero beta. No funds except SBI magnum in the year 2010-11, ICICI prudential in the year 2011-12 had negative betas, that shows all the funds are dependent on the market's performance. Comparison of annual returns with that of the beta, we find that almost all funds in FY 2010-11 \& FY 2012-13 have generated good returns and their beta coefficients are also less than 0.5. This implies that the funds produced higher returns for lower risk when compared to risk return relationship.

\section{Multiple R}

(a)FY 2010-11: Most of the funds have positive correlation and the values are within 0.5 only SBI Magnum has negative value.

(b)FY 2011-12: Reliance Large Cap has zero correlation and ICICI has negative value. Most of the funds have values less than 0.54

(c)FY 2012-13: All the funds have very less $R$ values and no funds have negative values.

Even the multiple $\mathrm{R}$ reveals that there is no strong significant correlation between the funds return and that of the benchmark. SBI 


\section{ELK Asia Pacific Journals}

$\underline{\text { www.elkjournals.com }}$

Magnum Bluechip in the year 2010-11 and ICICI Prudential Top 200 in the year 2011-12 have negative betas and negative R values. HDFC Top 200 in the FY 2012-13 has zero R; this indicates that there is less dependency of funds performance on that of benchmark.

\section{$\underline{\text { R Squared }}$}

(a)FY 2010-11: SBI and CanaraRobeco have zero R squared values. Most of the funds have very less $\mathrm{R}$ squared values.

(b)FY 2011-12: ICICI has zero value and Reliance Large Cap has zero R squared values.
(c)FY 2012-13: Most of the funds have zero $R$ squared values.

R SQR values are also very low and in the year 2012-13 all the funds except one have zero R SQR. This highlights that the fund's returns cannot be explained fully by the movements in the market. This again shows that there is very low correlation between the fund's returns and that of the benchmark. The above three statistical measures $\left(\beta, \mathrm{R}, \mathrm{R}^{2}\right)$ values calculated indicates that the actively managed funds do not mirror their respective benchmarks, which is the crux of active management

Table 4: Standard Deviation, Beta, Multiple ' $R$ ' and $R^{2}$ of sample and Benchmark Funds

\begin{tabular}{|c|c|c|c|c|c|c|c|c|c|c|c|c|}
\hline Year & \multicolumn{4}{|c|}{ 2010-11 } & \multicolumn{4}{|c|}{ 2011-12 } & \multicolumn{4}{|c|}{ 2012-13 } \\
\hline Fund & SD & BETA & $\mathrm{R}$ & $\mathrm{R}^{2}$ & SD & BETA & $\mathrm{R}$ & $\mathrm{R}^{2}$ & SD & BETA & $\mathrm{R}$ & $\mathrm{R}^{2}$ \\
\hline Axis Equity & 19.34 & 0.45 & 0.49 & 0.24 & 20.52 & 0.58 & 0.11 & 0.01 & 11.87 & 0.14 & 0.11 & 0.01 \\
\hline HDFC Top 200 & 17.16 & 0.45 & 0.49 & 0.24 & 26.63 & 0.16 & 0.16 & 0.02 & 13.10 & 0.01 & 0.00 & 0.00 \\
\hline $\begin{array}{l}\text { Birlasunlife Top } \\
100\end{array}$ & 13.66 & 0.46 & 0.51 & 0.26 & 24.57 & 0.44 & 0.52 & 0.27 & 14.41 & 0.16 & 0.17 & 0.03 \\
\hline $\begin{array}{l}\text { CanaraRobeco } \\
\text { Equity Diversified }\end{array}$ & 14.93 & 0.44 & 0.05 & 0.00 & 20.59 & 0.11 & 0.14 & 0.02 & 11.41 & 0.03 & 0.04 & 0.00 \\
\hline $\begin{array}{l}\text { Franklin India } \\
\text { Opportunities }\end{array}$ & 17.18 & 0.32 & 0.26 & 0.07 & 18.84 & 0.28 & 0.25 & 0.06 & 15.07 & 0.06 & 0.06 & 0.00 \\
\hline $\begin{array}{l}\text { ICICI Prudential } \\
\text { Top } 200\end{array}$ & 18.94 & 0.52 & 0.52 & 0.27 & 27.76 & -0.07 & -0.07 & 0.00 & 13.82 & 0.03 & 0.04 & 0.00 \\
\hline $\begin{array}{l}\text { JP Morgan India } \\
\text { Equity }\end{array}$ & 17.23 & 0.48 & 0.52 & 0.27 & 18.16 & 0.14 & 0.16 & 0.02 & 11.70 & 0.03 & 0.04 & 0.00 \\
\hline $\begin{array}{l}\text { Reliance focused } \\
\text { Large Cap }\end{array}$ & 9.96 & 0.42 & 0.48 & 0.23 & 29.57 & 0.00 & 0.00 & 2.90 & 0.17 & 0.02 & 0.03 & 0.00 \\
\hline $\begin{array}{l}\text { SBI Magnum } \\
\text { Bluechip }\end{array}$ & 16.76 & -0.07 & -0.08 & 0.00 & 22.74 & 0.12 & 0.02 & 0.15 & 16.83 & 0.08 & 0.1 & 0.01 \\
\hline $\begin{array}{l}\text { UTI } \\
\text { opportunities }\end{array}$ & 15.06 & 0.45 & 0.51 & 0.26 & 21.10 & 0.44 & 0.54 & 0.29 & 12.58 & 0.1 & 0.11 & 0.01 \\
\hline INDEX: NIFTY & 15.52 & & & & 23.19 & & & & 10.29 & & & \\
\hline INDEX: BSE 100 & 26.18 & & & & 26.18 & & & & 10.12 & & & \\
\hline INDEX :BSE 200 & 15.46 & & & & 23.2 & & & & 9.18 & & & \\
\hline
\end{tabular}

measures as already mentioned will be discussed

The previous analysis included discussions on the funds absolute return without adjusting to the risk and few statistical measures. Risk adjusted in the following sections.

\section{Sharpe Measure}




\section{ELK Asia Pacific Journals}

$\underline{\text { www.elkjournals.com }}$

Sharpe's measure, the reward-to-variability ratio or excess return over standard deviation is a common criterion for tracking performance of mutual funds. It measures the reward to-(total-) volatility tradeoff. The results are summarized in the table 5. Higher the Sharpe`s ratio better is the performance of the fund and vice-versa. The Sharpe's ratios in the year 2011-12 are all negative just like the annual returns (Table3) of the same year. Even though most of the funds had positive returns in 2012-13 but there Sharpe

Table 5: Sharpe's Ratio ratios are negative. There is no fund that has consistent Sharpe ratio and rank. Most of the funds have performed well in one year but not in the other years. Reliance focused Large Cap has the highest Sharpe ratio during the study period. Many of the funds have negative Sharpe ratio, this is because the excess return above the risk free rate is adjusted to standard deviation and standard deviation cannot be negative. This is the major limitation of Sharpe ratio.

\begin{tabular}{|c|c|c|c|c|c|c|}
\hline Year & \multicolumn{2}{|c|}{$2010-11$} & \multicolumn{2}{|c|}{ 2011-12 } & 2012-13 & Rank \\
\hline Axis Equity & -0.58 & 8 & -0.70 & 9 & 0.62 & 2 \\
\hline HDFC Top 200 & 0.47 & 1 & -0.55 & 4 & -0.63 & 10 \\
\hline Birlasunlife Top 100 & 0.39 & 3 & -0.58 & 5 & 0.08 & 3 \\
\hline $\begin{array}{l}\text { CanaraRobeco Equity } \\
\text { Diversified }\end{array}$ & 0.16 & 5 & -0.37 & 2 & -0.56 & 9 \\
\hline $\begin{array}{l}\text { Franklin India } \\
\text { Opportunities }\end{array}$ & -0.11 & 6 & -0.95 & 10 & -0.37 & 8 \\
\hline ICICI Prudential Top 200 & -0.18 & 7 & -0.63 & 7 & -0.09 & 6 \\
\hline JP Morgan India Equity & 0.30 & 4 & -0.26 & 1 & -0.26 & 7 \\
\hline Reliance focused Large Cap & -1.37 & 10 & -0.62 & 6 & 1.85 & 1 \\
\hline SBI Magnum Bluechip & -0.65 & 9 & -0.68 & 8 & 0.06 & 4 \\
\hline UTI opportunities & 0.40 & 2 & -0.48 & 3 & -0.06 & 5 \\
\hline
\end{tabular}

\section{Jensen`s Alpha}

Jensen's measure is the average return on the portfolio over and above that predicted by the CAPM, given the portfolio's beta and the average market return. Jensen's measure is the portfolio's alpha value. This measure was developed to evaluate the skill of active managers in stock picking. Higher the alpha value better is the fund performance and vice versa. A positive alpha means the fund has beaten the market. The negative alpha indicates underperformance of the fund with respect to the expected return. The alpha values of the sample 


\section{ELK Asia Pacific Journals}

$\underline{\text { www.elkjournals.com }}$

funds are tabulated in Table 6. Annual returns of the funds and Sharpe ratios for the year 2011-12 are similar with negative figures. Only one fund HDFC Top 200 has ranked $1^{\text {st }}$ in years 2010-11, 2011-12. But no other funds have shown

Table 6: Jensen Alpha Ratio (J. A.) consistency in ranks. This shows that funds performance varied in all the three years. Most of the funds have underperformed their benchmarks.

\begin{tabular}{|c|c|c|c|c|c|c|}
\hline \multirow[t]{2}{*}{ Year } & \multicolumn{2}{|c|}{ 2010-11 } & \multicolumn{2}{|c|}{ 2011-12 } & \multicolumn{2}{|c|}{$2012-13$} \\
\hline & JA & Rank & JA & Rank & JA & Rank \\
\hline Axis Equity & -12.14 & 9 & -4.22 & 3 & 7.52 & 1 \\
\hline Birlasunlife Top 100 & 4.43 & 4 & -6.43 & 5 & 1.34 & 2 \\
\hline HDFC Top 200 & 8.00 & 1 & 3.54 & 1 & -2.00 & 7 \\
\hline $\begin{array}{l}\text { CanaraRobeco Equity } \\
\text { Diversified }\end{array}$ & 2.40 & 5 & -5.73 & 4 & -6.26 & 10 \\
\hline $\begin{array}{l}\text { Franklin India } \\
\text { Opportunities }\end{array}$ & -1.75 & 6 & -13.08 & 7 & -5.38 & 9 \\
\hline ICICI Prudential Top 200 & -3.34 & 7 & -18.70 & 10 & -1.20 & 6 \\
\hline JP Morgan India Equity & 5.29 & 2 & -6.94 & 6 & -2.93 & 8 \\
\hline $\begin{array}{l}\text { Reliance focused Large } \\
\text { Cap }\end{array}$ & -14.43 & 10 & -18.40 & 9 & 0.35 & 4 \\
\hline SBI Magnum Bluechip & -10.76 & 8 & -13.28 & 8 & 1.06 & 3 \\
\hline UTI opportunities & 5.12 & 3 & -2.42 & 2 & -0.65 & 5 \\
\hline
\end{tabular}

\section{Information Ratio}

The information ratio divides the alpha of the portfolio by the tracking error (standard deviation of the outperformance w.r.t benchmark) of the portfolio. It measures abnormal return per unit of risk which can be
Information ratio is often used to indicate the effectiveness of a fund manager as it quantifies the performance of a portfolio. Higher information ratio is better which indicates better stock picking by fund manager. It is also called Appraisal ratio. In the FY 2011-12, Information ratios are almost positive for all the funds except 


\section{ELK Asia Pacific Journals}

$\underline{\text { www.elkjournals.com }}$

for Reliance focused Large Cap fund, whereas Sharpe ratio and Jensen alpha were negative for most of the funds in that year. No fund has Table 7: Information Ratio (I. R.) consistent information ratio throughout the period of study. No funds have same ranks in all the measures during the period of study.

\begin{tabular}{|c|c|c|c|c|c|c|}
\hline \multirow[t]{2}{*}{ Year } & \multicolumn{2}{|c|}{$2010-11$} & \multicolumn{2}{|c|}{ 2011-12 } & \multicolumn{2}{|c|}{ 2012-13 } \\
\hline & IR & Rank & IR & Rank & IR & Rank \\
\hline Axis Equity & -0.02 & 5 & 0.03 & 1 & 0.03 & 2 \\
\hline Birlasunlife Top 100 & 0.01 & 3 & 0.00 & 3 & 0.01 & 4 \\
\hline HDFC Top 200 & 0.03 & 1 & 0.01 & 2 & 0.00 & 5 \\
\hline $\begin{array}{l}\text { CanaraRobeco Equity } \\
\text { Diversified }\end{array}$ & -0.09 & 7 & 0.03 & 1 & 0.00 & 5 \\
\hline $\begin{array}{l}\text { Franklin India } \\
\text { Opportunities }\end{array}$ & 0.00 & 4 & 0.01 & 2 & -0.01 & 6 \\
\hline ICICI Prudential Top 200 & 0.02 & 2 & 0.01 & 2 & 0.00 & 5 \\
\hline JP Morgan India Equity & 0.02 & 2 & 0.01 & 2 & 0.00 & 5 \\
\hline $\begin{array}{l}\text { Reliance focused Large } \\
\text { Cap }\end{array}$ & -0.05 & 6 & -0.03 & 4 & 0.02 & 3 \\
\hline SBI Magnum Bluechip & 0.00 & 4 & 0.01 & 2 & 0.04 & 1 \\
\hline UTI opportunities & 0.02 & 2 & 0.03 & 1 & 0.01 & 4 \\
\hline
\end{tabular}

factors, market conditions and factors specific to

\section{Conclusions}

Analyzing the portfolio performance is a critical aspect for investors to select mutual fund for investment. There are many measures to evaluate the performance of mutual funds, but there is no one best method. Apart from the selected measure, there are other factors which influence the performance of the fund like macro economic the funds. Our study found that performance of the funds primarily depends on the measure selected for analysis. There were no funds which had common ranks with respect to different performance measures used. Many of the actively managed funds have not been able to outperform their respective benchmarks in the period of study. The frequency of measurement plays an important role in performance analysis. 


\section{ELK Asia Pacific Journals}

$\underline{\text { www.elkjournals.com }}$

\section{References:}

[1] Chen, H.-L., N. Jegadeesh, et al. (2000). "The Value of Active Mutual Fund Management: An Examination of the Stockholdings and Trades of Fund Managers." Journal of Financial and Quantitative Analysis 35(03): 343-368. http://dx.doi.org/10.2307/2676208

[2] David Blake, T. C., Christos Ioannidis, et al. (2014). "'New evidence on mutual fund performance: a comparison of alternative bootstrap methods" " Pensions Institute at Cass Business School.

[3] Jain, S. (July-Aug. 2012). "Analysis of Equity Based Mutual Funds in India." IOSR Journal of Business and Management (IOSRJBM) Volume 2(Issue 1).

[4] Mallikarjuna Rao, R. R. (2013). "Risk adjusted performance evaluation of selected balanced mutual fund schemes in india." Scholars world-Volume.1 (Issue.2).

[5] Nicolas P. B. Bollen, J. A. B. (2004). "ShortTerm Persistence in Mutual Fund Performance." Review of Financial Studies Volume 18,( Issue 2): Pp. 569-597.
[6] Pastor, L. a. S., Robert F (July 23, 2012). "On the Size of the Active Management Industry." Working Paper.

[7] Petajisto, A. (2013). "Active Share and Mutual Fund Performance." Financial Analysts Journal 69 no 4((July/August)): 7393.

[8] Sharpe, W. F. (1991). "The Arithmetic of Active Management." "Financial Analysts $\begin{array}{llll}\text { Journal" } & \text { Vol. 47: pp. }\end{array}$ http://dx.doi.org/10.2469/faj.v47.n1.7

\section{Websites:}

1. http://www.forbes.com

2. http://www.nerdwallet.com

3. http://www.cfainstitute.org

4. http://www.cassknowledge.com

5. http://www.vangaurd.com 


\section{ELK Asia Pacific Journals}

$\underline{\text { www.elkjournals.com }}$

Appendix 'A': List of sample mutual fund and corresponding benchmarks.

\begin{tabular}{ll}
\hline \multicolumn{1}{c}{ Selected Funds } & Benchmark \\
\hline Large Capitalization Funds & \\
1. Axis Equity fund & \\
2. Birla Sunlife Top 100 fund & CNX NIFY \\
3. JP Morgan India Equity Fund & CNX NIFTY \\
4. Can Robeco Equity Diversified fund & BSE 200 \\
5. HDFC Top 200 fund & BSE 200 \\
6. ICICI Pru Top 200 fund & BSE 200 \\
7. SBI Bluechip fund & BSE 200 \\
8. Reliance Focused Large Cap fund & BSE 100 \\
9. Franklin India Opportunities & CNX NIFTY \\
10. UTI Equity fund & BSE 200 \\
\end{tabular}

